\title{
ADVERTISEMENTS FOR ICT PROJECT MANAGERS SHOW DIVERSITY BETWEEN SWEDISH EMPLOYERS' AND PROJECT MANAGEMENT ASSOCIATIONS' VIEWS OF PM CERTIFICATIONS
}

Siw Lundqvist, Leif Marcusson

Linnaeus University, Sweden

E-mail: siw.lundqvist@Inu.se, leif.marcusson@Inu.se

\begin{abstract}
Appointing ICT project managers is a delicate issue for management; not least since ICT projects are known to be unsuccessful in delivering the required product in time and on budget. Hence, it is even more important to find the "right" individual for the job. According to project management associations, certification in project management is a prerequisite for a project manager's successful career. The appreciation of project management certifications among Swedish employers was studied using data collected from job advertisements for ICT project managers during four years (2010-2013). Judged on how the advertisements were worded the result indicates surprisingly low interest from the employers' side, which conflicts with the project management associations statements about the certifications' indispensable value for successful projects. Furthermore, it conflicts with a common understanding of certifications as essential for appointment as a project manager. The findings identify a possible gap between PM associations' and employers' views regarding the certifications'value, and highlight the necessity of seriously considering whether it is worthwhile for the individuals to strive for, and for the organizations to promote certification, since it is costly in both time, effort and money.
\end{abstract}

Key words: project manager, project management certifications, project management associations.

\section{Introduction}

It is vital for projects in general that they are carried out as successfully as possible not least because of the great effort that is required from all the involved parties. The efforts could be expressed in both monetary and human terms. A project is carried through as a process of connected, coherent activities and in order to be regarded as successful as it is expected to deliver satisfaction to the customer (and other interested parties) on time and within budget according to given specifications (e.g. IPMA, 2006; PMI, 2008; Antvik \& Sjöholm, 2012). Besides, project managers must be prepared to handle chaos and monitor complexity (e.g. Thomas \& Mengel, 2008). In addition, a project's success criteria differ depending on the type of project, but also due to different industries, nationalities, individuals, life cycle phases and organizations (Müller \& Turner, 2007; Müller \& Judgev, 2012). Hence, it is vital that a project is well managed and this makes it essential to hire "the right" project manager. From the early days of project management, particularly in the armed forces, the methods gradually spread to other industries/sectors, and this lead to a need for synchronization and to a standardization of methods and theories. This was important at the time, not least because project managers needed an arena for co-operation and support. Standardization activities, from which certifi- 
Siw LUNDQVIST, Leif MARCUSSON. Advertisements for ICT Project Managers Show Diversity between Swedish Employers' and Project Management Associations' Views of PM Certifications

PROBLEMS

OF MANAGEMENT IN THE $21^{\text {st }}$ CENTURY Vol. 9, No. 1, 2014

36

cation programs were derived, were seen as means for developing project management as a profession (e.g. Blomquist \& Söderholm, 2002; Blomquist \& Thomas, 2004; Myrén, 2013). Project management associations were established and some significant examples are: i) the International Project Management Association (IPMA, 2006) that started in 1965, in Vienna (under the name International Management Systems Association) now Swiss registered, ii) the Project Management Institute (PMI, 2008), founded in 1969 in the US, and iii) Prince2 (2007) that was developed in 1989, in the UK. In Sweden IPMA and PMI are behind the project management credentials that are most frequently applied for. IPMA have certified 150000 people worldwide. During 2012 PMI surpassed 500000 active project management professionals, i.e. PMP (Project Management Professional) credentials in 190 countries. Sweden had about 1600 certified project managers January 2012 (PMI, 2012).

Project management certifications are often mentioned as means for project managers to develop their skills, and many project managers/members have obtained certificates throughout the years (fewer however in Sweden). Project management associations propagate the necessity of certification in order to manage successful projects. These are the common arguments for justifying the certification programs that likewise raise questions about whether it is necessary or not for project managers to be certified if they are to be appointed as an ICT project managers. The situation for ICT project managers is special because the general opinion in the ICT business is that project management certifications are necessary since employers usually demand that programmers and technicians show a variety of credentials e.g. Microsoft's ICT certifications (Blomquist \& Söderholm, 2002; Cornerstone, 2013) and therefore project managers should do likewise. The fact that ICT project managers are surrounded by well-qualified ICT professionals at least when compared to project managers in other lines of business. That is why this study focuses on ICT-project managers since the reasoning behind project management certifications seems to be the most interesting one. It is usually up to the individual project manager to decide whether he/she should engage in a certification program or not, if the employers do not especially set out to hire certified project managers. Employers could also demand project managers without these credentials to commit to certification programs. Hence, the individuals' choices could sometimes be somewhat limited.

Opinions about the need for project management certifications are divided. On one hand, there are voices from project managers, with many years of experience in the trade, who discredit the value of certifications because of the great investments that have to be made e.g. time and effort (in addition to the cost). A survey from 2009 found that nine out of ten project managers, who were not project management certified, were convinced that this was a fact that did not, in any way, obstruct their opportunities of being appointed (Löwenfeldt, 2009). A study carried out in Australia and New Zealand found that $20.47 \%$ of job advertisements for project managers mentioned certification among the required competence qualifications (Ahsan, Ho, \& Khan, 2013). On the other hand, spokespersons from the Swedish branches/chapters of the international project management associations strongly recommend certifications, particularly when it comes to successfully carried through salary negotiations (The Swedish Computer Society, 2009). A ranking of the 15 top paying certifications for 2013, which was carried out by the Global Knowledge, puts PMP (i.e. The PMI's project management professional certification) in the top position (Muller, 2013). It is a common understanding that a project manager could gain a higher status simply by attaining a project management certification (Blomquist \& Thomas, 2004 ) and a project management certification is known to boost a project manager's CV since it provides a proof of quality (Myrén, 2013). 
Siw LUNDQVIST, Leif MARCUSSON. Advertisements for ICT Project Managers Show Diversity between Swedish Employers' and Project Management Associations' Views of PM Certifications

\section{Purpose}

The purpose of this study was to explore if project management certifications have a value for ICT project managers on the Swedish labor market.

\section{Research Question}

Is there a demand for project management certification in Swedish job advertisements for ICT project managers?

\section{Methodology of Research}

\section{General Background of Research}

An inductive, longitudinal study over a period of four years (2010-2013) has been carried out exploring 325 job advertisements for ICT project managers in Sweden. The 325 advertisements originate from the 158 companies included in the study; advertisements and companies are viewed from the perspectives "Industry" and "Market" regarding certification aspects (see Figure 1).

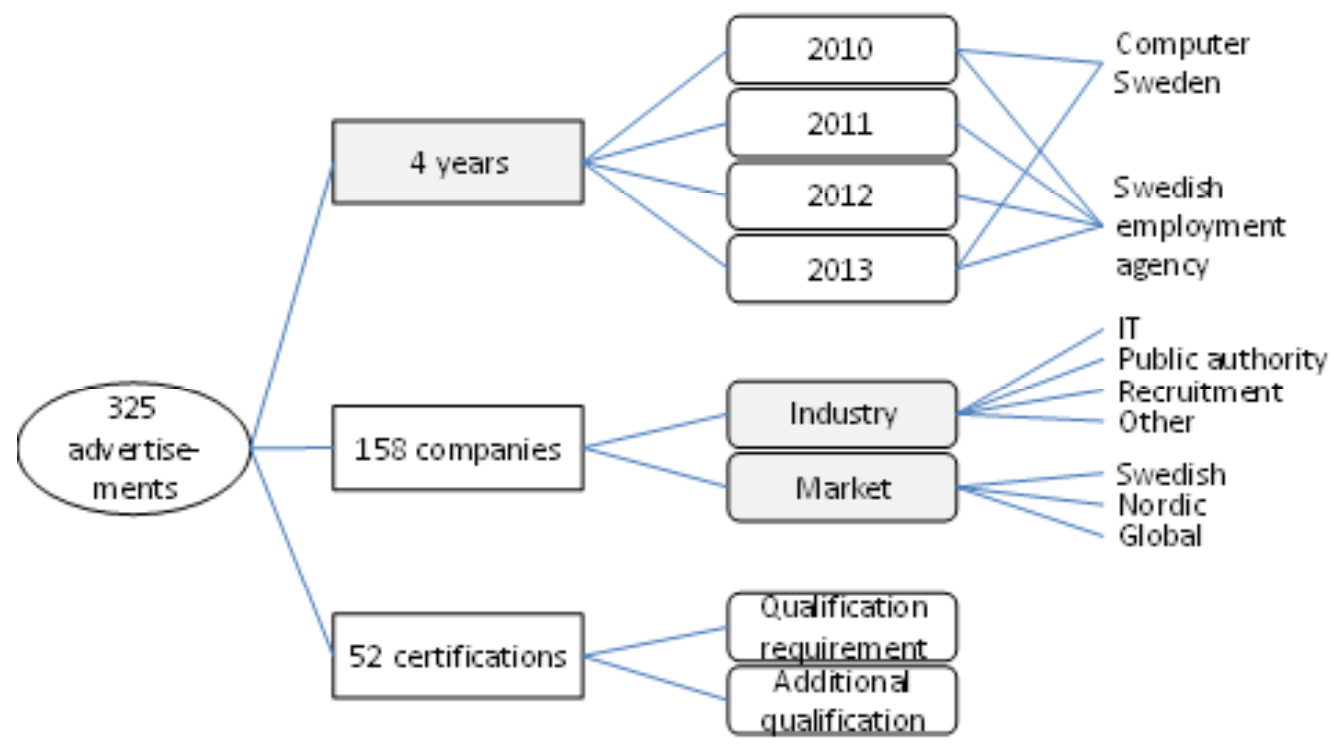

\section{Figure 1: The study's content.}

The study is qualitatively and quantitatively analyzed (Krippendorff, 2004; Holzmann \& Spiegler, 2010). The literature review was mainly carried out after the data was collected and the analysis had started.

\section{Sample Seletion}

Job advertisements regarding ICT project managers have been collected once yearly i.e. at the end of February or at the beginning of March over a period of four years $(2010-2013)$. 
Siw LUNDQVIST, Leif MARCUSSON. Advertisements for ICT Project Managers Show Diversity between Swedish Employers' and Project Management Associations' Views of PM Certifications

PROBLEMS

OF MANAGEMENT

IN THE $21^{\text {st }}$ CENTURY Vol. 9, No. 1, 2014

Behind the decision to collect data once a year lie the following considerations: i) an opportunity to follow changes, if there were any, on a longitudinal basis and ii) ensuring that sufficient time had passed in order to avoid collecting the same advertisements. However, the latter might have been feasible even with shorter intervals, e.g. quarterly or twice a year.

The advertisements were collected from the publication Computer Sweden's job advertisement's website, which is a common place for ICT project manager advertisements in Sweden, and from the Swedish employment agency, also available online. They were printed out and analyzed in order to investigate if and how requirements of project management certifications were mentioned and described. A total of 325 advertisements are included in the study (see Table 1).

Table 1. ICT Project Manager.

Advertisements

\begin{tabular}{lc}
\hline Year & Numbers of advertisements \\
\hline 2010 & 79 \\
\hline 2011 & 93 \\
\hline 2012 & 62 \\
\hline 2013 & 91 \\
\hline Total sum & 325 \\
\hline
\end{tabular}

The collection of these job advertisements has geographically included Sweden as a whole. As regards the years of 2010 and 2013 data has been collected from two sources (AF and CS) which convey a risk for redundancy when both sources were simultaneously employed. In order to avoid misleading data, the material was searched for duplicates. When two similar advertisements were found in both AF and CS, one of them was removed.

\section{Instrument and Procedures}

The research method was chosen in order to gain an understanding of how employers value project management certifications when hiring ICT project managers. Content analysis of the advertisements was applied as a research tool and the study uses integrated qualitative and quantitative approaches. The qualitative content analysis provides the conceptual framework and the quantitative content analysis provides measurable terms for the framework (Krippendorff, 2004; Holzmann \& Spiegler, 2010). The content analysis was carried out by using word count. The basis for the word count was words that began with "certif" in order to cover both certified and certification. These words were put in relation to whether they were mentioned as qualification requirements or as additional requirements. Furthermore, they were put in relation to market and industry. Market was grouped into Swedish, Nordic and global. Industry was grouped into ICT, Public authority, Recruitment and Other.

The study applied to advertisements instead of questionnaires or interviews in order to avoid employers being tempted to talk warmly for the need of certifications or against it without being convinced of either of the alternatives. It is well known that interviewees sometimes try to adapt their opinions to what is expected of them in a given situation (e.g. Thång, 1984; Gummesson, 2001). The advertisements, on the other hand, are what they are and are not touched up because of the ongoing study. The decision to search for and collect advertisements once yearly relates to the fact that it is rather easy to drown in an overload of information (e.g. Kvale, 2006) and the longitudinal perspective was considered to be helpful when it comes to provid- 
Siw LUNDQVIST, Leif MARCUSSON. Advertisements for ICT Project Managers Show Diversity between Swedish Employers' and Project Management Associations' Views of PM Certifications

ing a realistic picture of what is requested in job advertisements for ICT project managers in Sweden. After the first data material was collected and analyzed in 2010, ten employers (who had advertised for ICT project managers) were contacted for further interviews; something that turned out to be a total failure (only one was interested). Hence the findings from the content analysis were not followed up with interviews.

When choosing a method for a study there is always a question about finding a valid and reliable way of collecting the empirical material. In this case the advertisements provided information about if, and how, certifications were mentioned. The fact that the data collection was carried out once a year between 2010 and 2013 indicates the stability of the findings because the findings hardly differ within these four years. Regarding possibilities for generalization we refer to Gummesson (2001) who argues that too much weight is often given to generalization; a search for the best solution at a certain time would often outdo a traditional wish for generalization.

\section{Literature Review}

\section{Benefits of Project Management Certifications}

There are some basic assumptions on project management certification that point out commonly perceived benefits: i) guarantee of quality, ii) verification of competences, iii) independently carried out reviews i.e. third-party inspections of a company's project management competences, iv) increased credibility and trust, v) a mutual language and a foundation for understanding between co-operating project partners, vi) competence development and development of project management as a profession, and vii) a career path for project managers. Additionally, there could also be many individual needs and triggers behind an individual's decision to commit to voluntary certification programs e.g. to boost one's CV (Blomquist \& Söderholm, 2002; Blomquist \& Thomas, 2004; King, Lenox, \& Terlaak, 2005; IPMA, 2013; Makar, 2013; Muller, 2013; Myrén, 2013; PMI 2013). Being certified as a project manager could be a way of showing that a person is qualified and could also provide a higher status for individuals who do not have a university education (Morris, Crawford, Hodgson, Shepherd, \& Thomas, 2006).

Certifications as such could also reduce information asymmetries mentioned by King et al. (2005, p. 1092) who "theorize that firms use the public act of certification to reduce 'information asymmetries' between suppliers and potential buyers" since information that is unequally distributed (asymmetric information) could have a negative influence on all parties. In any case, certifications could be a way of showing that a person is suitably qualified and it could also provide status for individuals without formal education in the field of project management Morris et al. (2006). The study carried out by King et al., (2005) supports the claim that such certifications are useful to support the information requirements of external partners both nationally and internationally as well as when a vertical relationship is apparent between buyer and seller. Certifications were used for facilitating the information needs and for preventing threats of opportunism that otherwise could appear. According to Myrén (2013) Swedish authorities are more interested in certifications than others.

\section{Why Project Managers Pursue Certification Programs}

Blomquist and Thomas (2004) carried out a study among over 1400 project managers (both certified and not certified) to investigate their motivation behind aspiring to project management certification. The response rate was just under $30 \%$ and $55 \%$ of those respondents who participated had some kind of project management certification. $33 \%$ worked in the ICTsector. The most frequent reasons for the decision to carry through with certification plans were: 
Siw LUNDQVIST, Leif MARCUSSON. Advertisements for ICT Project Managers Show Diversity between Swedish Employers' and Project Management Associations' Views of PM Certifications

PROBLEMS

OF MANAGEMENT IN THE $21^{\text {st }}$ CENTURY Vol. 9, No. 1, 2014

i) a wish to challenge oneself and meet professional standards (85\%), ii) to provide evidence of proficiency in project management $(85 \%)$, iii) to increase credibility as project manager (81\%), iv) to increase knowledge of project management, and v) to become even more marketable for other jobs (81\%) (Blomquist \& Thomas, 2004). The two most important reasons for not certifying was that certifications were not considered as necessary in their present organization ( $64 \%$ of those who had no certificate) and that they did not have time to study in accordance with the certification program (61\%). Of those who did not have certificates $70 \%$ revealed that this had nothing to do with a lack of project management experience (which is usually required for being part of certification programs) nor was a lack of knowledge about the certification programs a factor for not taking part in the programs (69 \%) (Blomquist \& Thomas, 2004).

Morris et al., (2006) discuss the consumers of knowledge products (Book/Bodies of Knowledge - BOKs). Major companies are large consumers of service and training regarding standardization i.e. of certification programs. They invest in these products because they seek some kind of assurance for their project practices, and believe that they will get it through the professionalization of the project managers who are expected to pass the certification programs (Morris et al., 2006).

\section{Concerns about Project Management Certifications}

Although there are many voices heard, mainly from the project management associations, associated educators and people who are certified, urging the necessity of gaining project management certifications, there are also more critical opinions questioning their usefulness and relevance. King et al., (2005) argue that managers, who feel required to satisfy partners' need for credible information about the organization's projects, are more willing to implement certification programs. A problem with this reasoning is that although it is reasonable to believe that certification should reflect the use of management standards, the opposite cannot be assumed. It is fairly likely that organizations that do not certificate still might adopt parts or all of a certain standard. Organizations that had gone through certification programs still might disengage from the standards. Adopting a standard is an internal act and certification is an external act (King et al., 2005).

Stevenson and Starkweather's (2010) study among ICT recruiters and executives showed that in a first step of the study in which the ICT recruiters were asked to mention characteristics that they look for in potential candidates they ranked PMP certifications as irrelevant. The second part of the study asked ICT executives to rank the characteristics from the ICT recruiters ranking and this showed that the ICT executives ranked PMP certification as second (worst) among those categories that were ranked as irrelevant (Stevenson \& Starkweather, 2010). In another study Starkweather and Stevenson (2011) tested two hypotheses regarding the value of PMP certifications as a core competence and as an indicator of project success. Both were rejected since the data pointed to PMP certifications being the least valued of 15 competencies and that there was no difference regarding project success if the project managers were certified or not (Starkweather \& Stevenson, 2011).

\section{The Standards behind Certification Programs Are Questioned}

Project management associations have developed standards and certification programs used are used all over the world, to assure that project managers have the necessary qualifications. These certifications are based on the standards that have been developed through a qualitative work process in which experienced practitioners' collective opinions and judgments, of what is needed in order to lead effective projects, have been decisive. Crawford (2005) argues that she lacks research in the field of project management and its standardization process, since 
the existing research results are based only on practitioners' opinions and research findings

from the field of behavioral science. The latter do not cover issues that are dealt with in the standards and the former has a limited and solely practical perspective. Morris et al., (2006) agree about the problems concerning the bodies of knowledge (BOKs) and certification programs, even though they have been increasingly popular. The perceived problems are connected to agreements on the BOKs, including whether the project management associations really have the competence to create those BOKs, as well as the value of certification, which is also viewed as rather uncertain. Morris et al., (2006) question the relevance of the BOKs' descriptions of the professional area of competence. The most critical issue is whether the guidelines (on which the certifications are based) that were developed many years ago are still relevant or if they are too dated to be appropriate. PMI's first PMBOK (Project Management Body of Knowledge) was established in 1976 and published in 1983. Several other project management associations established their own guidelines over the following 10-15 years, but since then practically no changes have been made. Morris et al. (2006) agree with Crawford $(2000,2005)$ and question if practitioners, who developed the standards behind the BOKs, had the necessary competence to determine what should be requested for being certified as a project manager. They consider that researchers' findings should be more influential on the guidelines than they have been so far.

Much research has been carried out in the field of project management but there is barely anything that is transferred to the standards and guidelines behind the certification programs. According to Morris et al. (2006) an important reason, for this lack of implementation of research findings, could be that it would entail considerable time end efforts to update the complex certification infrastructure (i.e. the BOKs). Furthermore, certified project professionals could risk losing their certification or should need to update it (at considerable cost and effort) if the requirements were continually updated. The authors (Morris et al., 2006) discuss the paradox that lies in these certifications. On the one hand, they should guarantee project performance and on the other hand, those who are certified do not want the standards (that their certification builds on) to be altered since it would be an impediment for themselves; not least because they lose their advantage over those who are not certified. In addition, they are often reluctant to change their way of working and do not want to pay for upgrading their certification.

\section{Relationships between Standards and Project Performance Are Questioned}

Earlier research in the area of project management competence is mostly based on opinions of the project managers themselves. Hence, Crawford (2000) took on a more objective approach for her study and collected data in which she related project management standards to a separately derived rating of workplace performance. The data were collected from 350 project personnel and five instruments were used: i) collecting demographic information, ii) a knowledge test (multiple choice questions from the PMBOK), iii) a self-assessment against standards, iv) a self-rating questionnaire and v) a supervisor rating questionnaire. Furthermore a literature review was carried out investigating earlier research findings and Crawford (2000) found that the project management standards did not address the two factors from her literature review, argued to be the most crucial ones for project management performance. These factors were leadership and technical performance. Because leadership is connected to personality and technical performance usually applies to various, specific application areas, it was obvious (and also understandable) that these two perspectives were not covered by the standards. Crawford's (2000) findings, however, indicate that there is hardly any direct relationship between workplace performance, as it was perceived, and the standards. Nor was there a direct relationship between the standards and earlier research findings about project performance (2000).

Crawford (2005), who argues that present research is insufficient regarding the relation between the following of standards and of being competent and effective as a project manager, 
Siw LUNDQVIST, Leif MARCUSSON. Advertisements for ICT Project Managers Show Diversity between Swedish Employers' and Project Management Associations' Views of PM Certifications

PROBLEMS

OF MANAGEMENT IN THE $21^{\text {st }}$ CENTURY Vol. 9, No. 1, 2014

continued her empirical studies on these subjects. Findings from her study based on the PMBOK standards show that there were no statistically significant relationships between performance against standards, in their entirety, and project management performance as it was perceived by senior managers. Nevertheless, there were patterns of positive and negative relationship between parts of the standard and perceptions of performance; use of integrative activities overall had decreasing likelihood of being perceived as a top performer even though they were given high importance in the standards. Monitoring and checking time and cost had increased likelihood of being perceived as a top performer. Furthermore, this study indicated that there were differences between the opinions of practitioners and senior managers regarding what they considered to be good knowledge and practice for project managers. In order to be perceived as a top performer by senior management it was found to be important to manage project finalization and to avoid engaging in general management tasks (Crawford 2005).

Morris et al. (2006) also doubt that the certification programs have been influential on the improvement of project delivery and outcomes. This is a delicate and seldom questioned subject even though Crawford (2005) did not find any significant correlation between standards and performance. According to Morris et al. (2006) this is something that is highly interesting to look into since there are many, who perceive the certification programs and BOKs as valid promises for effectively run projects that deliver what is expected. A certification is meant to indicate that a professional has both the necessary knowledge about BOKs and practice from project management. Notwithstanding this, certifications cannot guarantee high performance even though someone who is certified apparently managed to show/do what was needed in order to get the certificate. In any case, those who follow the standards are considered to perform more effectively than others (Morris et al., 2006).

It is risky to consider the BOKs as best practices according to Morris et al. (2006); not least because they are seldom updated and the many available research findings are rarely reflected upon. Morris et al. (2006) question whether certifications should really be regarded as an important key for development of project management as a profession and propose further research in that area. Examples of issues to deal with in further research are according to Morris et al. (2006): Should certification be a way to bar and hinder people who are not certified, but still being competent and skilled as a project manager, from taking on project management assignments? What litigations would it provoke if only certified project managers could be appointed?

\section{The Importance of Project Management Certifications for Boosting Project Managers' Careers and for Influencing the Professionalization of Project Management}

Project management certifications are often considered to be influential on how project management evolves as a profession. Müller and Turner (2010) start the discussion about project manager's competence and qualifications to have blossomed since the year 2000. Project managers often represent a large part of an organization's leadership competence but their careers are seldom mentioned in literature covering career models. It is increasingly important for organizations in general to keep their project competence "in house", which triggers the development of career models. Hence, career models are seen as something that ties project managers closer to the actual organization, instead of seeking new assignments in other companies when a certain project is finished. Bredin and Söderlund (2013) state that the project management associations' have striven ambitiously towards making the project manager's role formalized and professionalized. Nevertheless, they noted that it took many years before the associations' hard work with their certification programs had any particular impact on companies' development of career plans for their project managers. Hence, the authors (Bredin \& Söderlund, 2013) propose that many companies today have implemented a certification framework concurrently 
promoting the role of project managers as a career ladder. This could be risky because aligning

with external bodies of knowledge could promote their mobility and facilitate their opportunities of new appointments instead of staying in an organization that actually promoted, and paid for, their certification. An organization's opportunities to control a career model must be regarded as limited since they should rely on external associations to gain legitimacy (Bredin \& Söderlund, 2013).

Shenhar and Dvir (2007) point out the need for establishing training programs for project managers in order to motivate them to participate in competence development activities and to stay in business. Furthermore, they emphasize the importance of assuring prospective project managers that taking on these responsibilities is worthwhile because it will boost their careers. Project managers have traditionally often been recruited for temporary assignments which could diminish the employers' willingness to offer competence development. An organization should gain from providing project managers with favorable opportunities for competence development and career programs because it is likely to be helpful for keeping them in the organization. Otherwise, it is likely that they keep on moving from one organization's project to another's (Shenhar \& Dvir, 2007). Another positive factor of career models is that they could reduce project mangers' feelings of stress and of being out of control (Lindgren \& Packendorff, 2009). According to Morris et al. (2006) standardization of project management and certification of project managers are steps that lead to a formal process of professionalization for project managers. The professionalization process is by some considered as very important for gaining higher status (Blomquist \& Thomas, 2004; Myrén, 2013).

\section{Career Models and the Professionalization of Project Management}

Also Bredin and Söderlund (2013) discuss the importance of career models for project managers, an issue that they consider far too little acknowledged. During Bredin and Söderlund's (2013) research of ten large and mature project-intensive Swedish companies, they found two archetypes of career models that these firms used: i) the competence strategy model and ii) the talent management model. The competence strategy model (applied at Saab, Ericsson and Sandvik) mainly focussed on the organizations' needs, the strategic evolution and growth areas and not on individual competence development plans. Three of the studied companies (Posten, Volvo Aero and Scania) had not implemented career models for project managers at all. The talent management model (applied at ABB, AstraZeneca, TeliaSonera and Skanska) focused on individualized development opportunities for the project managers i.e. the individual's needs and requirements were more interesting than the organization's. Three of the studied companies (Posten, Volvo Aero and Scania) had not implemented career models for project managers at all. Reasons for not implementing career models were for example, that “... the company does not wish to 'lock' people into certain careers but instead encourages mobility across different types of management positions and assignments" (Bredin \& Söderlund, 2013, p. 898). One HR manager from Volvo Aero spoke about the managers' and co-workers' "invisible ladder" for careers (Bredin \& Söderlund, 2013, p 898). Notwithstanding this, the companies had implemented extensive training programs for project managers.

The reasons behind the seven companies' decisions to implement a career model could be grouped into four themes: i) to build and attract project manager's competence, ii) to get a common language for communication, iii) to provide transparency about the employees' career opportunities and iv) to provide recognition opportunities for project professionals. The companies that Bredin and Söderlund (2013) studied, that had implemented career models, had mostly based them on the existing guidelines from IPMA or PMI; some complemented those with more levels but did not see any need to develop their own model from scratch. Nevertheless, the career models were not always applied in the process of assigning project managers 
Siw LUNDQVIST, Leif MARCUSSON. Advertisements for ICT Project Managers Show Diversity between Swedish Employers' and Project Management Associations' Views of PM Certifications

OF MANAGEMENT

IN THE $21^{\text {st }}$ CENTURY Vol. 9, No. 1, 2014

(eg. at Skanska) and sometimes project managers were assigned from a "gut feeling" (Bredin \& Söderlund, 2013, p 899) as a project management director from TeliaSonera expressed it. Just one of the companies studied (Saab) applied training programs that exactly corresponded to the levels in their career model that were linked to IPMA's levels (Bredin \& Söderlund, 2013). Even though they had developed training programs those were often not connected to the career model. At Saab the project managers were certified according to IPMA's guidelines and certification programs and this was the case in several of the companies that were studied.

King et al., (2005) point out that it is not guaranteed that a certain PM standard is being fully and practically implemented after certification and there is also a risk for decoupling. Furthermore, their study (King et al., 2005) found that firms with lower performance tended to certify more and this conflicts with earlier findings that propose that certifications serve as signals of high performance (King et al., 2005).

\section{Results of Research}

The following three subsections contain tables divided by advertisements (see Tables 2, 4 and 6) and companies (tables 3, 5 and 7) put in relation to "Industry" (see Tables 4 and 5) and "Market" (see Tables 6 and 7) regarding certification interest from the employers' side (judged by how the advertisements are worded). Hence, in the tables partitioned by industry/market the percentage figures are calculated in three different ways that are further described in the "Industry" section and referred to as A, B and C in tables $4-7$.

Note that the actual figures for companies in Table 3 are 196 (not 158 as in the remaining tables), reflecting the fact that some companies were represented more than one year. Note also that all percentages figures are rounded to one decimal digit.

\section{Years}

Certification was mentioned in 52 advertisements either as a qualification requirement or as an additional qualification. There were $14(4.3 \%)$ advertisements that mentioned project management certification among the qualification requirements and $38(11.7 \%)$ advertisements that mentioned certification as an additional qualification (see Table 2). In total, $16 \%$ of the advertisements mentioned certification in some way, either as a qualification requirement or as an additional qualification. The year 2011 stands out both regarding certification mentioned as a qualification requirement $(8.6 \%)$ and as an additional qualification $(5.4 \%)$ but when the comprised figures are analyzed the result for $2011(14 \%)$ hardly stands out at all even though the year 2011 shows the lowest percentages. When the advertisement texts were analyzed there were generally no particular "brands" of certifications mentioned, but when examples were given explicitly the certifications from PMI and IPMA were emphasized. 
Table 2. Advertisements Sorted by Year.

\begin{tabular}{lllllll}
\hline Year & $\begin{array}{l}\text { Numbers of } \\
\text { advertisements }\end{array}$ & \multicolumn{2}{l}{$\begin{array}{l}\text { QR }=\text { Qualification } \\
\text { Requirements }\end{array}$} & \multicolumn{2}{l}{$\begin{array}{l}\text { AQ = Additional } \\
\text { Qualification }\end{array}$} & $\begin{array}{l}\text { Comprised figures } \\
\text { QR + AQ }\end{array}$ \\
\hline 2010 & 79 & 2 & $2.5 \%$ & 13 & $16.4 \%$ & $19.0 \%$ \\
\hline 2011 & 93 & 8 & $8.6 \%$ & 5 & $5.4 \%$ & $14.0 \%$ \\
\hline 2012 & 62 & 2 & $3.2 \%$ & 7 & $11.3 \%$ & $14.5 \%$ \\
\hline 2013 & 91 & 2 & $2.1 \%$ & 13 & $14.3 \%$ & $16.5 \%$ \\
\hline & 325 & 14 & $4.3 \%$ & 38 & $11.7 \%$ & $16.0 \%$ \\
\hline
\end{tabular}

Table 3. Companies Sorted by Year.

\begin{tabular}{|c|c|c|c|c|c|c|}
\hline \multirow{2}{*}{$\begin{array}{l}\text { Year } \\
2010\end{array}$} & \multirow{2}{*}{$\begin{array}{l}\text { Numbers of } \\
\text { companies }\end{array}$} & \multicolumn{2}{|c|}{$\begin{array}{l}\text { QR = Qualification } \\
\text { Requirements }\end{array}$} & \multicolumn{2}{|c|}{$\begin{array}{l}\mathrm{AQ}=\text { Additional } \\
\text { Qualification }\end{array}$} & \multirow{2}{*}{$\begin{array}{l}\text { Comprised figures } Q R \\
+A Q \\
20.0 \%\end{array}$} \\
\hline & & 2 & $5.0 \%$ & 6 & $15.0 \%$ & \\
\hline 2011 & 58 & 5 & $8.6 \%$ & 5 & $8.6 \%$ & $17.2 \%$ \\
\hline 2012 & 45 & 2 & $4.4 \%$ & 6 & $13.3 \%$ & $17.8 \%$ \\
\hline \multirow[t]{2}{*}{2013} & 53 & 2 & $3.8 \%$ & 7 & $13.2 \%$ & $17.0 \%$ \\
\hline & 196 & 11 & $5.6 \%$ & 24 & $12.2 \%$ & $17.9 \%$ \\
\hline
\end{tabular}

Tables 2 and 3 show proportionately similar figures regarding the interest in certified project managers, only to be expected since it is likely that a company's fundamental perspectives are reflected in their job advertisements. Table 3 shows a similar picture regarding the figures for year 2011 as was pointed out in Table 2. The findings shown in Tables 2 and 3 indicate that the data collection has reached saturation point.

\section{Industry}

Industry is divided into "ICT", "Public authority", "Recruitment" and "Other". The four categories were chosen because of their perceived relevance for certifications of ICT project managers. The "ICT" category was almost self-evident due to the study's focus on ICT project managers' need for certification in the Swedish labor market. The category "Public authority" was chosen since it is a sector that employs many people in Sweden. Furthermore, the authorities' ICT functionalities, including security/integrity aspects, are fundamental to that sector's core function of providing better service to citizens. Companies in the staffing industry, in the category "Recruitment" are placed there because their advertisements did not reveal the company/line of business behind the advertisements or it was not made obvious which line of industry they applied to anyway. The "Other" category covers those remaining. However, all advertisements concern appointments as ICT project managers.

In the Tables 4 and 5, three (A, B and C) arithmetical operations/calculations are applied.

A) Number of advertisements/companies (accounted for by industry) divided by the total sum of advertisements/companies in the same column and number of certification requirements (i.e. number of advertisements/companies that mentioned certifications in some way) divided by the total number of certification requirements in the same column. 
Siw LUNDQVIST, Leif MARCUSSON. Advertisements for ICT Project Managers Show Diversity between Swedish Employers' and Project Management Associations' Views of PM Certifications

PROBLEMS

OF MANAGEMENT

IN THE $21^{\text {st }}$ CENTURY Vol. 9, No. 1, 2014

46

B) Number of certification requirements divided by the number of advertisements (accounted for by industry) on the same row.

C) Number of certification requirements divided by the total number of advertisements/ companies.

Table 4 presents the advertisements classified by industry and the employer's shown interest in certifications.

Table 4. Advertisements Accounted for by Industry.

\begin{tabular}{|c|c|c|c|c|c|c|c|}
\hline \multirow[t]{2}{*}{ Industry } & \multirow[b]{2}{*}{$\begin{array}{l}\text { Arithmetical } \\
\text { operations }\end{array}$} & \multicolumn{2}{|c|}{ Advertisements } & \multicolumn{2}{|c|}{$\begin{array}{l}\text { Certification } \\
\text { requirements }\end{array}$} & \multicolumn{2}{|c|}{ Calculation of percentages } \\
\hline & & $\mathbf{N}$ & $\%$ & $\mathbf{N}$ & $\%$ & $\%$-units & $\%$ \\
\hline \multirow[t]{3}{*}{ ICT } & A & 170 & 52.3 & 35 & 67.3 & +15.0 & +28.7 \\
\hline & $B$ & & & & 20.6 & & \\
\hline & C & & & & 10.8 & & \\
\hline \multirow[t]{3}{*}{ Public authority } & A & 22 & 6.8 & 6 & 11.5 & +6.6 & +94.1 \\
\hline & B & & & & 27.3 & & \\
\hline & C & & & & 1.8 & & \\
\hline \multirow[t]{3}{*}{ Recruitment } & A & 90 & 27.7 & 10 & 19.2 & -8.5 & -30.7 \\
\hline & B & & & & 11.1 & & \\
\hline & C & & & & 3.1 & & \\
\hline \multirow[t]{3}{*}{ Other } & A & 43 & $13.2 \%$ & 1 & $1.9 \%$ & -11.3 & -85.6 \\
\hline & $B$ & & & & 2.3 & & \\
\hline & C & & & & 0.0 & & \\
\hline \multirow[t]{3}{*}{ Total } & A & 325 & 100.0 & 52 & 100.0 & & \\
\hline & $\mathrm{B}$ & & & & * 16.0 & & \\
\hline & C & & & & * 16.0 & & \\
\hline
\end{tabular}

Table 5 presents the companies classified by industry and the employer's shown interest in certifications. 
Siw LUNDQVIST, Leif MARCUSSON. Advertisements for ICT Project Managers Show Diversity between Swedish Employers' and Project Management Associations' Views of PM Certifications

Table 5. Companies Accounted for by Industry.

\begin{tabular}{|c|c|c|c|c|c|c|c|}
\hline \multirow[t]{2}{*}{ Industry } & \multirow[b]{2}{*}{$\begin{array}{l}\text { Arithmetical } \\
\text { operations }\end{array}$} & \multicolumn{2}{|c|}{ Companies } & \multicolumn{2}{|c|}{$\begin{array}{l}\text { Certification } \\
\text { requirements }\end{array}$} & \multicolumn{2}{|c|}{ Calculation of percentages } \\
\hline & & $\mathrm{N}$ & $\%$ & $\mathbf{N}$ & $\%$ & $\%$-units & $\%$ \\
\hline \multirow[t]{3}{*}{ ICT } & $A$ & 75 & 47.5 & 18 & 62.1 & $+14.6 \%$ & +30.7 \\
\hline & $\mathrm{B}$ & & & & 24.0 & & \\
\hline & C & & & & 11.4 & & \\
\hline \multirow[t]{3}{*}{ Public authority } & A & 14 & 8.9 & 4 & 13.8 & $+4.9 \%$ & +55.1 \\
\hline & $B$ & & & & 28.6 & & \\
\hline & C & & & & 2.5 & & \\
\hline \multirow[t]{3}{*}{ Recruitment } & A & 33 & 20.9 & 6 & 20.7 & $-0.2 \%$ & -0.01 \\
\hline & B & & & & 18.2 & & \\
\hline & C & & & & 3.8 & & \\
\hline \multirow[t]{3}{*}{ Other } & $A$ & 36 & 22.8 & 1 & 3.4 & $-19.4 \%$ & -85.1 \\
\hline & B & & & & 2.8 & & \\
\hline & C & & & & 0.6 & & \\
\hline \multirow[t]{3}{*}{ Total } & A & 158 & 100.0 & 29 & 100.0 & & \\
\hline & $B$ & & & & * 18.4 & & \\
\hline & $\mathrm{C}$ & & & & * 18.4 & & \\
\hline
\end{tabular}

Tables 4 and 5 points in the same direction; it is clear that "ICT" and "Public authority" are overrepresented. The most important findings are summarized in the following points. The "ICT industry" has:

- a larger share of advertisements (67.3\%) compared to their share of total advertisements $(53.3 \%)$, giving the highest figures regarding percentage units $(15.0 \%)$ and the second highest figures regarding the calculation of percentages $(28.7 \%$ ) (cf. arithmetical operation/calculation A)

- a larger share of companies (62.1\%) compared to their share of total companies (47.5\%), giving the highest figures regarding percentage units (14.6\%) and the second highest figures regarding the calculation of percentages $30.7 \%$ ) (cf. A)

- the second highest percentages for advertisements (20.6\%) and for companies $(24.0 \%)(\mathrm{cf} . \mathrm{B})$

- the largest share for advertisements (10.8\%) and companies (11.4\%) (cf. C).

The "Public authority" has:

- a larger share of advertisements (11.5\%) compared to their share of the total advertisements $(6.8 \%)$, which gives the second highest figures for percentage units $(6.6 \%)$ the highest figures regarding the calculation of percentages (94.1\%) (cf. A) 
Siw LUNDQVIST, Leif MARCUSSON. Advertisements for ICT Project Managers Show Diversity between Swedish Employers' and Project Management Associations' Views of PM Certifications

PROBLEMS

OF MANAGEMENT IN THE $21^{\text {st }}$ CENTURY
Vol. 9, No. 1,2014

- a larger share of companies (13.8\%) compared to their share of total companies $(8.9 \%)$, which gives the second highest figures for percentage units $(4.9 \%)$ and the highest figures regarding the calculation of percentages (55.1\%) (cf. A)

- the highest percentages for advertisement (27.3\%) and for companies (28.6\%) (cf. B).

\section{Market}

The market categories were chosen because of their perceived relevance for certifications for ICT project managers. The "Swedish" market is obvious in this study of the Swedish labor market. The "Nordic" is the geographical area where the constituent countries traditionally have close relationships. The "Global" is everything outside "Nordic". Firstly, table 6 shows findings related to advertisements sorted by market $(\mathrm{N}=325)$. Secondly, table 7 presents findings that concern companies sorted by market $(\mathrm{N}=158)$. The arithmetical operations $(\mathrm{A}, \mathrm{B}$ and C) are the same as for the industry (see Findings).

Table 6. Advertisements Accounted for by Market.

\begin{tabular}{|c|c|c|c|c|c|c|c|}
\hline \multirow[t]{2}{*}{ Market } & \multirow[b]{2}{*}{$\begin{array}{l}\text { Arithmetical } \\
\text { operations }\end{array}$} & \multicolumn{2}{|c|}{ Advertisements } & \multicolumn{2}{|c|}{$\begin{array}{l}\text { Certification } \\
\text { requirements }\end{array}$} & \multicolumn{2}{|c|}{ Calculation of percentages } \\
\hline & & $\mathbf{N}$ & $\%$ & $\mathrm{~N}$ & $\%$ & $\%$-units & $\%$ \\
\hline \multirow[t]{3}{*}{ Swedish } & $A$ & 175 & 54.0 & 20 & 38.0 & -16.0 & -29.6 \\
\hline & $\mathrm{B}$ & & & & 11.4 & & \\
\hline & C & & & & 6.2 & & \\
\hline \multirow[t]{3}{*}{ Nordic } & A & 34 & 10.0 & 5 & 10.0 & 0.0 & 0.0 \\
\hline & B & & & & 14.7 & & \\
\hline & C & & & & 1.5 & & \\
\hline \multirow[t]{3}{*}{ Global } & A & 116 & 36.0 & 27 & 52.0 & +16.0 & +29.6 \\
\hline & $B$ & & & & 23.3 & & \\
\hline & C & & & & 8.3 & & \\
\hline \multirow[t]{3}{*}{ Total } & A & 325 & 100.0 & 52 & 100.0 & & \\
\hline & $B$ & & & & * 16.0 & & \\
\hline & $C$ & & & & * 16.0 & & \\
\hline
\end{tabular}


Siw LUNDQVIST, Leif MARCUSSON. Advertisements for ICT Project Managers Show Diversity between Swedish Employers' and Project Management Associations' Views of PM Certifications

Table 7. Companies Accounted for by Market.

\begin{tabular}{|c|c|c|c|c|c|c|c|}
\hline \multirow[t]{2}{*}{ Market } & \multirow[b]{2}{*}{$\begin{array}{l}\text { Arithmetical } \\
\text { operations }\end{array}$} & \multicolumn{2}{|c|}{ Companies } & \multicolumn{2}{|c|}{$\begin{array}{l}\text { Certification } \\
\text { requirements }\end{array}$} & \multicolumn{2}{|c|}{ Calculation of percentages } \\
\hline & & $\mathrm{N}$ & $\%$ & $\mathrm{~N}$ & $\%$ & $\%$-units & $\%$ \\
\hline \multirow[t]{3}{*}{ Swedish } & $A$ & 87 & 55.0 & 13 & 46.0 & -9.0 & -16.4 \\
\hline & $B$ & & & & 14.9 & & \\
\hline & C & & & & 8.2 & & \\
\hline \multirow[t]{3}{*}{ Nordic } & $A$ & 16 & 10.0 & 2 & 7.0 & -3.0 & -30.0 \\
\hline & $B$ & & & & 12.5 & & \\
\hline & C & & & & 1.3 & & \\
\hline \multirow[t]{3}{*}{ Global } & $A$ & 55 & 35.0 & 13 & 46.0 & +11.0 & +31.4 \\
\hline & $B$ & & & & 23.6 & & \\
\hline & C & & & & 8.2 & & \\
\hline \multirow[t]{3}{*}{ Total } & $A$ & 158 & 100.0 & 28 & 100.0 & & \\
\hline & $B$ & & & & * 17.7 & & \\
\hline & $\mathrm{C}$ & & & & * 17.7 & & \\
\hline
\end{tabular}

Tables 6 and 7 point in the same direction; "Global" is overrepresented with the highest figures for all calculations of percentages, both regarding advertisements and companies.

\section{Discussion}

\section{Standards both Praised and Questioned}

Project management associations and their partners, researchers and journalists have throughout the years warmly recommended certifications stressing the necessity of being certified in order to effectively lead projects that deliver what is required by sponsors and other stakeholders (e.g. Blomquist \& Thomas, 2004; the Swedish Computer Society, 2009; IPMI, 2013; Muller, 2013; PMI, 2013). The view of certifications as quality assurance towards copartners and other clients, e.g. in reducing information asymmetries, is also often raised (e.g. King et al., 2005). The low employer interest that became evident in the findings from the advertisements (cf. Tables 2 and 3 ) is a reason for doubting that these positively pronounced arguments have, in fact been influential. Prior research has discussed some critical issues regarding which actors actually define the standards, i.e. those who stand behind the BOKs, that the project management certifications build on. Some researchers have objected to the fact that these people were foremost practitioners, who might lack an overall view of a project as a whole (even though they are experts on their own specific part), and senior managers who often have biased opinions because of their specific viewpoints and technical competences (Crawford, 2000, 2005, 2006). Both Morris et al., (2006) and Crawford (2000, 2005, 2006) seriously doubt that the standards were objectively designed since those who were involved were not likely to master the necessary knowledge and skills. Hence, it could be questioned whether the certifications per se convey any specific value. The self-assessment that is embedded in the certification programs is also sometimes questioned. Prior studies have proved that top managers (who often act as project sponsors) seldom find exact compliance with standards (BOKs) necessary for 
Siw LUNDQVIST, Leif MARCUSSON. Advertisements for ICT Project Managers Show Diversity between Swedish Employers' and Project Management Associations' Views of PM Certifications

PROBLEMS

OF MANAGEMENT IN THE $21^{\text {st }}$ CENTURY Vol. 9, No. 1, 2014

50 top project performance, as practitioners tend to think (e.g. Crawford, 2000, 2005). Recent research findings about project management are seldom reflected in the standards and guidelines produced by the project management associations (Morris et al., 2006). The research findings, which show low employer interest in certified ICT-project managers, could be influenced by the occasionally expressed uncertain use of certifications (e.g. Crawford, 2000, 2005; Morris et al., 2006) but this study does not investigate the underlying causes.

When the standards behind project management certifications are questioned there are weaker grounds for relying on certifications as quality assurance (e.g. Crawford 2000, 2005; Morris et al., 2006). Hence, employers' willingness to pay higher salaries to certified project managers is likely to be reduced as will the higher status of certified project managers (cf. Blomquist \& Thomas, 2004; Löwenfeldt, 2009; the Swedish Computer Society, 2009; Cornerstone, 2013). This is due to difficulties in pricing consultancy services higher when using certified project managers, especially since there are other ways of convincing partners of one's ability to successfully complete a project, for example prior successful results. The BOKs' intentions could be followed even without project managers with specific project management certifications (Morris et al., 2006).

\section{Certifications Do Not Guarantee Project Success}

The standards behind the certifications have hardly been updated or modified since they were introduced in the 1980s (Morris et al., 2006). A lot of research has been carried out and the findings are not implemented in the BOKs and transferred to the certification programs. These are facts that are likely to lower expectations of project management certifications as a guarantee for project success. It could be claimed that certifications even provide a false sense of security and that certified project managers do not always put the BOKs into practice (which could be the case). These are examples of issues that the employers might struggle with when appointing project managers. Research findings even show that less successful organizations have shown tendencies towards applying certifications to a higher degree than others (King et al., 2005). Findings about low (if any) statistically significant relations between following standards and workplace performance (Crawford 2000, 2005; Stevenson \& Starkweather, 2010; Starkweather \& Stevenson, 2011) add further to the doubts about the usefulness and necessity of project management certifications.

It is sometimes proposed that project managers who are able to show these credentials are better paid (e.g. the Swedish Computer Society, 2009), which from the employers' perspective could be regarded a drawback if the certifications' usefulness is not convincing per se. Although the lack of certification may be considered a barrier to appointment (Morris et al., 2006) the empirical findings do not point in that direction. Rather the opposite is rather indicated judging by how the job advertisements were worded. The study showed that employers put little value on their prospective project managers being certified.

This is especially apparent in the figures that show how often certifications are mentioned among the qualification requirements $(4.3 \%$, see Table 2$)$ in the advertisements. Even major Swedish enterprises tend to certify to a small extent even though they often engage in building career models for project managers. This is sometimes done by using project management associations' BOKs even if they do not always follow up by getting the credentials. Engaging in professionalization of project managers by building career models is a way of tying them closer to the company in order to keep their competences in-house instead of having to search for new managers after each project (Shenhar \& Dvir, 2007; Müller \& Turner, 2010; Bredin \& Söderlund, 2013). Besides, career models could reduce the project managers' feelings of stress and exposure (Lindgren \& Packendorff, 2009). Nevertheless, employers do not solely rely on project management certifications as guarantees of project success as the research findings 
Siw LUNDQVIST, Leif MARCUSSON. Advertisements for ICT Project Managers Show Diversity between Swedish Employers' and Project Management Associations' Views of PM Certifications

indicate. Otherwise project management certifications should have been more frequently mentioned in the job advertisements.

\section{Some Employers Are More Interested in Hiring Certified ICT Project Managers Even Though the Total Picture Shows Relatively Low Interest}

From Tables 4 and 5 (see Findings) it can be concluded that the employers from the "ICT industry" and the "Public authority" have more interest in hiring certified ICT project managers compared to "Recruitment" and "Other" industries. These findings partly confirm Myrén's (2013) statement about Swedish public authorities as being especially interested in certifications compared to other areas of business. However, the "ICT industry" is also proportionately more interested in certifications, which confirms the project management associations' proclamations of certifications as important for project performance even though the total picture of the employers' interest in certifications is rather scarce and this applies to the "ICT industry" as well (eg. Blomquist \& Söderholm, 2002; Blomquist \& Thomas 2004; PMI, 2008; IPMA 2013; Myrén, 2013). It is not surprising that the "ICT industry" had the biggest share of the total advertisements since the empirical search concerned appointments regarding ICT project managers.

The Tables 6 and 7 (see Findings) show that Swedish companies acting on a "Global" market are far more interested in certifications than the "Swedish" and the "Nordic" markets (however, still a generally low interest). This is not surprising since the attitudes to certification programs, often established abroad, generally seem to be more positive and less questioning outside Sweden and the Nordic countries (e.g. IPMI, 2013; PMI, 2013).

\section{Overview of the Certification's Place in the Project Context}

Taking a standpoint in project management certifications (see Figure 2) it can be elucidated that the "Project Management Associations" have developed and own the "Standards" (i.e. the BOKs) that set the criteria for the "Certification" programs.

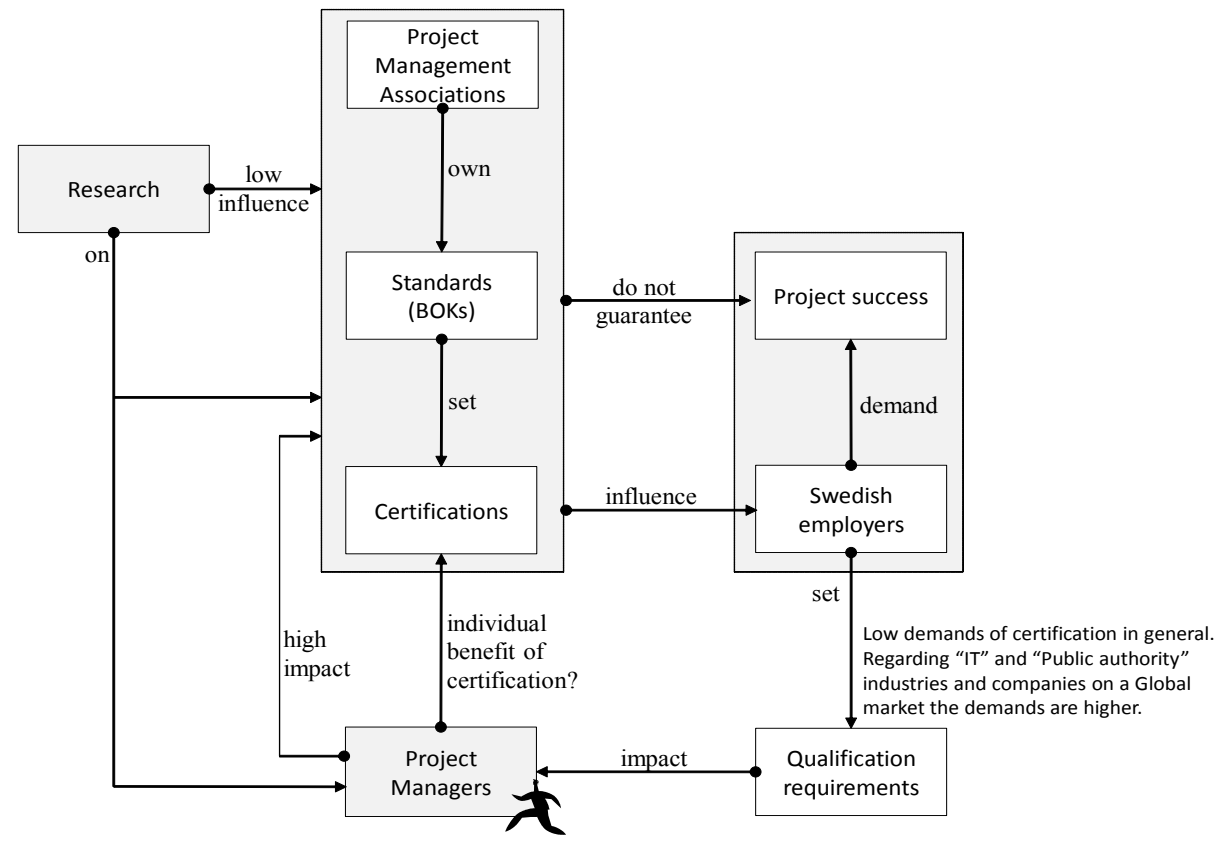

Figure 2: Overview of project certification. 
Siw LUNDQVIST, Leif MARCUSSON. Advertisements for ICT Project Managers Show Diversity between Swedish Employers' and Project Management Associations' Views of PM Certifications

PROBLEMS

OF MANAGEMENT

IN THE $21^{\text {st }}$ CENTURY Vol. 9, No. 1, 2014

Research findings concerning projects and "Project Managers" have had a low influence on "Project Management Associations", "Standards" and "Certifications" while the "Project managers" (i.e. the practitioners) have exerted high impact on them. The fact that the bodies of knowledge i.e. the "Standards" are written by practitioners is an important factor behind the critique about the "Standards" and therefore the "Certifications" (see Analysis and Discussion). "Project Managers" need to investigate if it will bring them any individual benefit if they take part in "Certification" programs. The "Swedish employers" demand that projects that are carried through in their organizations lead to "Project success", which is something that "Certifications", "Standards" or the "Project Management Associations" could not guarantee. The fact that the project team is certified does not guarantee project success per se. Nevertheless, the "Certifications", "Standards" and "Project Management Associations" influence the "Swedish employers" to some extent when they are setting the "Qualification requirements" before hiring "Project Managers". The employers' requirements have an impact on the "Project Managers" for example, when they decide whether or not they have anything to gain from committing to a certification program.

There are relatively few certified Swedish project managers (e.g. 1600 certified by the PMI standards) which could be caused by proportionately low interest in certification from the employers' side. However, even though employer interest for certification is proportionately low there are some who are particularly interested in certifications. These employers are found in the "Public authority" and the "ICT" industries as well as in companies acting on a "Global" market.

\section{Conclusions and Future Research}

The purpose of this study was to investigate if project management certifications have an explicitly expressed value for ICT project managers in the Swedish labor market. The more specific research question concerned whether Swedish job advertisements show any demand for project management certifications. The findings are clear about the proportionately low employer interest in project management certifications and there are few demands for certifications as a qualification requirement. Certifications are mentioned as an additional qualification criterion nearly three times as frequently - which still gives a rather low percentage figure when these criteria are put together. The low employer interest in project management certifications could influence project managers' commitment to taking part in certification programs and employers becoming even more hesitant about engaging in them. Hence, the implication for Swedish project managers is mainly a need to seriously consider the usefulness of following certification programs, not least when considering the major individual effort required. The employers on the other hand should carefully consider if their companies could benefit from acknowledging project management certifications any more than this study indicates. It is an important question because although certification programs are in question there are also recognized advantages.

The findings indicate diversity between how certified Swedish practitioners and employers interpret the value of project management certification. After all, there are some (e.g. 1600 PMI certified in January 2012) who are certified in Sweden and it is naturally important for them that their qualification profile and their certification status is not questioned or depreciated.

The "ICT industry" and the "Public authority" are the industries that pay attention to and value project management certifications, either as a qualification requirement or as an additional qualification. Companies acting on a "Global" market have a greater interest in certifications when hiring ICT project managers. Hence, ICT project managers who aim at being appointed in these industries could gain from getting the credentials for being certified as a project manager. 
Siw LUNDQVIST, Leif MARCUSSON. Advertisements for ICT Project Managers Show Diversity between Swedish Employers' and Project Management Associations' Views of PM Certifications

Implications of the findings

The implications could be divided in four different perspectives.

- Employers: The findings indicate that PM certifications are not regarded as valuable enough in order to motivate the effort required (costly in both time and money) to promote certification.

- The certification providers/other educators: The findings indicate that the value of the certification programs have not been sufficiently established in the Swedish ICT sector.

- ICT project managers: According to the findings, indicating that the employers are not particularly interested in certified ICT project managers, they have to carefully consider if it is worth striving for, and they should also investigate if there are other qualifications that the employers value higher.

- Research: The study's findings show a possible gap between PM associations' and employers' apprehensions regarding the certifications' value, which is interesting per se since there has been much focus on PM certifications over recent decades, and it is a business that involves much money.

\section{Proposals for future research}

Based on the findings that showed a proportionately and generally low interest for certifications it would be interesting to look further into the underlying causes for the employers' standpoints. Are they influenced by the fact that the standards behind the certification programs sometimes are seriously questioned? It would also be interesting to study the project managers'/workers' attitudes towards participating in certification programs. Are they aware of how employers value these certifications? Do they view certification as a path to higher status and better salary?

\section{Acknowledgements}

The authors would like to thank for insightful comments and suggestions, during this journal's double-blind review process, which have been most helpful for the improvement of this article.

\section{References}

Ahsan, K., Ho, M., \& Khan, S. (2013). Recruiting project managers: A comparative analysis of competencies and recruitment signals from job advertisements. Project Management Journal, 44 (5), 36-54.

Antvik, S., \& Sjöholm, H. (2012). Project management and methods. Lund, Sweden: Studentlitteratur.

Blomquist, T., \& Söderholm, A. (2002). How project management goes carried away. In K. Sahlin-Andersson \& A. Söderholm (Eds.), Beyond project management - New perspectives on the temporary-permanent dilemma. Malmö, Sweden: Liber.

Blomquist, T., \& Thomas, J. (2004). Project manager's perceptions of the motivation for, and benefits, of certification. In: Proceedings of IRNOP VI, Turku, Finland.

Bredin, K., \& Söderlund, J. (2013). Project managers and career models: An exploratory comparative study. International Journal of Project Management, 31, 889-902. 
Siw LUNDQVIST, Leif MARCUSSON. Advertisements for ICT Project Managers Show Diversity between Swedish Employers' and Project Management Associations' Views of PM Certifications

OF MANA MENT IN THE $21^{\text {st }}$ CENTURY Vol. 9, No. 1, 2014

54

Cornerstone (2013). Microsoft-certifiering. Retrieved January 24, 2014, from http://www.cornerstone.se/ certifieringar/microsoft

Crawford, L. (2000). Profiling the competent project manager. In: Project Management Research at the Turn of the Millennium, Proceedings of PMI Research Conference, 21 - 24 June, 2000, Paris, France, pp. 3-15. Sylva, NCL.

Crawford, L. (2005). Senior management perceptions of project management competence. International Journal of Project Management, 23, 7-16.

Gummesson, E. (2001). Qualitative Methods in Management Research. Thousand Oaks, CA: Sage Publications.

Holzmann, V., \& Spiegler, I. (2011). Developing risk breakdown structure for information technology organizations. International Journal of Project Management, 29, 537-54.

IPMA (2006). IPMA Competence Baseline. IPMA Nijkerk, Netherlands.

IPMA (2013). Certification. Retrieved April 4, 2014, from: http://ipma.ch/certification/

King, A. A., Lenox, M. J., \& Terlaak, A. (2005). The strategic use of decentralized institutions: Exploring certification with the ISO 14001 management standard. Academy of Management Journal, 48 (6), 1091-1106.

Krippendorff, K. (2004). Content analysis: An introduction to its methodology. London, England: SAGE Publications.

Kvale, S. (2006). Den kvalitativa forskningsintervjun. Lund, Sweden: Studentlitteratur.

Löwenfeldt, J. (2009). It-konsulter: Certifiering lönar sig inte. IT24 - Affärerna, marknaden och människorna. Retrieved February 8, 2014, from: http://it24.idg.se/2.2275/1.209950/it-konsulter-certifiering-lonar-sig-inte

Makar, A. (2013). Project managers'views on the value of a PMP certification, TechRepublic - Project Management. Retrieved February 8, 2014, from: http://www.techrepublic.com/blog/it-consultant/ project-managers-views-on-the-value-of-a-pmp-certification/

Morris, P. W. G., Crawford, L., Hodgson, D., Shepherd, M. M., \& Thomas, J. (2006). Exploring the role of formal bodies of knowledge in defining a profession - The case of project management. International Journal of Project Management, 24 (8), 710-721.

Müller, R., \& Turner, R. (2007). The influence of project managers on project success criteria and project success by type of project. European Management Journal, 25 (4), 298-309.

Müller, R., \& Jugdev, K. (2012). Critical success factors in projects: Pinto, Slevin and Prescott - the elucidation of project success. International Journal of Managing Projects in Business, 5 (4), 757-775.

Muller, R. (2013). 15 Top Paying Certifications for 2013. Retrieved February 13, 2014, from: http://www. globalknowledge.com/training/generic.asp?pageid $=3430 \&$ country $=$ United + States

Myrén, K. (2013). Certifieringar har mognat. CSJOBB, Computer Sweden. Retrieved February 13, 2014, from: http://csjobb.idg.se/2.9741/1.513393/certifieringar-har-mognat

PMI (2008). A Guide to the Project Management Body of Knowledge. Fourth edition, Newtown Square, Pennsylvania: PMI.

PMI (2012). Enhancing business value - around the world, 2012 Annual report. PMI Project Management Institute. Retrieved February 28, 2014, from: http://www.pmi.org/About-Us/ /media/PDF/ Publications/PMI\%202012\%20Annual\%20Report.ashx

PMI (2013). Why choose a PMI certification? Retrieved February 8, 2014, from: http://www.pmi.org/en/ Certification/Why-Choose-a-PMI-Certification.aspx

Prince2 (2007). Managing Successful Projects with Prince2. London, England: The Stationery Office.

Starkweather, J. A., \& Stevenson, D. H. (2011). PMP certification as a core competency: Necessary but not sufficient. Project Management Journal, 42 (1), 31- 41.

Stevenson, D. H., \& Starkweather, J. A. (2010). PM critical competency index: IT execs prefer soft skills. International Journal of Project Management, 28, 663-671.

The Swedish Computer Society (2009). Certifieringar allt viktigare för både lön och karriär. Dataföreningen - för kunskap och kontakter. Retrieved February 9, 2014, from: https://www.dfs. se/node/4158

Thomas, J., \& Mengel, T. (2008). Preparing project managers to deal with complexity - Advanced project management education. International Journal of Project Management, 26 (3), 304-315. 
Siw LUNDQVIST, Leif MARCUSSON. Advertisements for ICT Project Managers Show Diversity between Swedish Employers' and Project Management Associations' Views of PM Certifications

PROBLEMS

OF MANAGEMENT

IN THE $21^{\text {st }}$ CENTURY

Vol. 9, No. 1, 2014

Thång, P. O. (1984). Vuxenlärarens förhållningssätt till deltagarerfarenheter. Göteborg, Sweden: ACTA.

Tonnquist, B. (2012). Projektledning. Stockholm, Sweden: SanomaUtbildning.

Advised by Laima Railiene, University of Siauliai, Lithuania

Received: April 18, 2014

Accepted: April 29, 2014

Siw Lundqvist $\quad$ PhD., Assistant Professor, Linnaeus University, SE-391 82 Kalmar, Sweden.

E-mail: siw.lundqvist@Inu.se

Leif Marcusson

Ph.D., Assistant Professor, School of Business and Economics, Linnaeus University, SE-391 82 Kalmar, Sweden.

E-mail: leif.marcusson@Inu.se 